\title{
Conservation genetics of endangered leaf-beetle Cheilotoma musciformis populations in Poland
}

\author{
E. Kajtoch • D. Kubisz • D. Lachowska-Cierlik • \\ M. A. Mazur
}

Received: 16 December 2011/Accepted: 28 March 2012/Published online: 17 April 2012

(C) The Author(s) 2012. This article is published with open access at Springerlink.com

\begin{abstract}
Steppe-like habitats in Europe are seriously threatened as a result of fragmentation and anthropogenic degradation, at least in western and central parts. Considering the dramatic loss of steppe-like habitats, the evaluation of genetic variation in populations of steppe species is of immediate importance if appropriate conservation measures are to be undertaken. In this paper, we examine the genetic diversity of the highly endangered populations of the leaf-beetle Cheilotoma musciformis, which inhabits only a limited area in south-central Poland, which is geographically isolated from the continuous range of this species. Both mitochondrial and nuclear markers show that the Polish populations are distinct from Slovakian and Ukrainian ones. These regional populations should be considered independent conservation units. On the other hand, very little (mtDNA) or no (nuclear DNA) diversity has been found among the Polish subpopulations. This
\end{abstract}

Ł. Kajtoch $(\square)$

Department of Experimental Zoology, Institute of Systematics and Evolution of Animals, Polish Academy of Science, Sławkowska 17 St., 31-016 Cracow, Poland e-mail: kajtoch@isez.pan.krakow.pl

D. Kubisz

Department of Collections, Institute of Systematics and Evolution of Animals, Polish Academy of Science,

Sebastiana 9 St., 31-049 Cracow, Poland

D. Lachowska-Cierlik

Institute of Zoology, Jagiellonian University,

Gronostajowa 9, 30-387 Cracow, Poland

M. A. Mazur

Department of Biosystematics, Center for Biodiversity Studies, Opole University, Oleska 22 St., 45-052 Opole, Poland leads to the conclusion that this species has gone through a strong bottleneck leading to a drastic reduction in its genetic diversity prior to the establishment of present-day populations. Host plants have been identified for this species using barcodes, and the only hosts for the Polish and Ukrainian samples are sainfoins Onobrychis spp. while for the Slovakian sample it is either Dorycnium pentaphyllum or Lotus spp. (all Fabaceae). All of these data can be very valuable for the conservation of $C$. musciformis populations (e.g. for reintroductions).

Keywords Coleoptera Chrysomelidae - Evolutionary significant unit · Threaten population · Isolation · Steppe · Host plants

\section{Introduction}

Steppes and xerothermic habitats closely related to them are threatened environments in Europe, particularly in central and western parts. They contain communities rich in rare and endemic species, especially insects. In central and western Europe, xerothermic habitats are considered "warm-stage refugia" of steppes, which were more widespread during glaciations (Willis and Van Andel 2004; Ashcroft 2010). Steppe-like habitats are presently fragmented and limited to areas unfavorable for agriculture or forest plantations. Fragmentation of natural habitat is generally considered to be a major threat to many species, as it may lead to e.g. reduction of genetic diversity (e.g. Frankham et al. 2002). Consequently, evaluation of the extent of isolation of existing populations and of their genetic diversity is of major concern in assessing the risk of local extinction of any threatened taxa. The rarity of steppe-like habitats has led to their protection in reserves 
and in the Natura 2000 network of protected sites according to the Habitats Directive of the European Union. Many steppe species, especially plants and insects are threatened, but only a small portion of them are protected by local or European laws. Considering the loss of steppe-like habitats, particularly xerothermic grasslands as a consequence of the changes in land use that have taken place particularly in central and western Europe (Michalik and Zarzycki 1995; Mazur and Kubisz 2000; Varga 2001), but also in eastern and southern Europe (Palao 1909; Cremene et al. 2005), evaluation of genetic variation in steppe species populations is of immediate importance if appropriate conservation measures are to be undertaken. The best known xerothermic communities of insects in central and eastern Europe are Lepidoptera (Kostrowicki 1953; Cremene et al. 2005; Goloborod'ko and Fedenko 2008); Orthoptera (Liana 1987; Varga 2001) and Curculionidae (Mazur 2001). Xerothermic Chrysomelidae are little known (e.g., Wasowska 2006). So far few studies have been devoted to the genetics of steppe-like beetles: weevils (Kajtoch et al. 2009, 2011; Kajtoch and Lachowska-Cierlik 2009; Kajtoch 2011), leaf beetles (Kubisz et al. 2012) and tiger beetles (Diogo et al. 1999). There are many other species whose genetic diversity should be investigated, especially those whose populations are highly endangered, Cheilotoma musciformis (Goeze, 1777) being one of them.

Cheilotoma beetles are found only in the Palearctic region-mainly in western and central Asia (C. ivanovi Jacobson 1923, C. fulvicollis Sahlberg 1913, C. voriseki Medvedev and Kantner 2003, C. beldei Kasap 1984) and in northern Africa (C. rotroui Kocher 1961), and only two species are found both in Europe and Asia: C. erythrostoma (Faldermann 1837) and C. musciformis (Warchalowski 2003; Medvedev 2004; Regalin and Medvedev 2010). This last species has been divided into three subspecies: C. musciformis iranica (Medvedev 2004) (occurring in Iran), C. musciformis apennina (Medvedev 2004) (in southern Italy) and C. musciformis musciformis (Goeze 1777) (from France to the Caucasus and central Siberia). The fourth subspecies described by Medvedev (2004), C. musciformis hispanica, is probably synonymous with $C$. $m$. apennina. The range of $C$. musciformis musciformis is approximately continuous from France to central Asia; however, north of the Carpathians at least two highly isolated populations are known in southern Polish and western Ukrainian uplands (Fig. 1a). These last two populations are located $300-500 \mathrm{~km}$ from each other, and also isolated from the main species range (c. $300 \mathrm{~km}$ from the Polish-Slovakian populations and c. $350 \mathrm{~km}$ from the western Ukrainian-Black Sea populations). In Poland, this species has been known only in the southcentral uplands (Fig. 1b); however, in some of these localities this species has not been collected since the

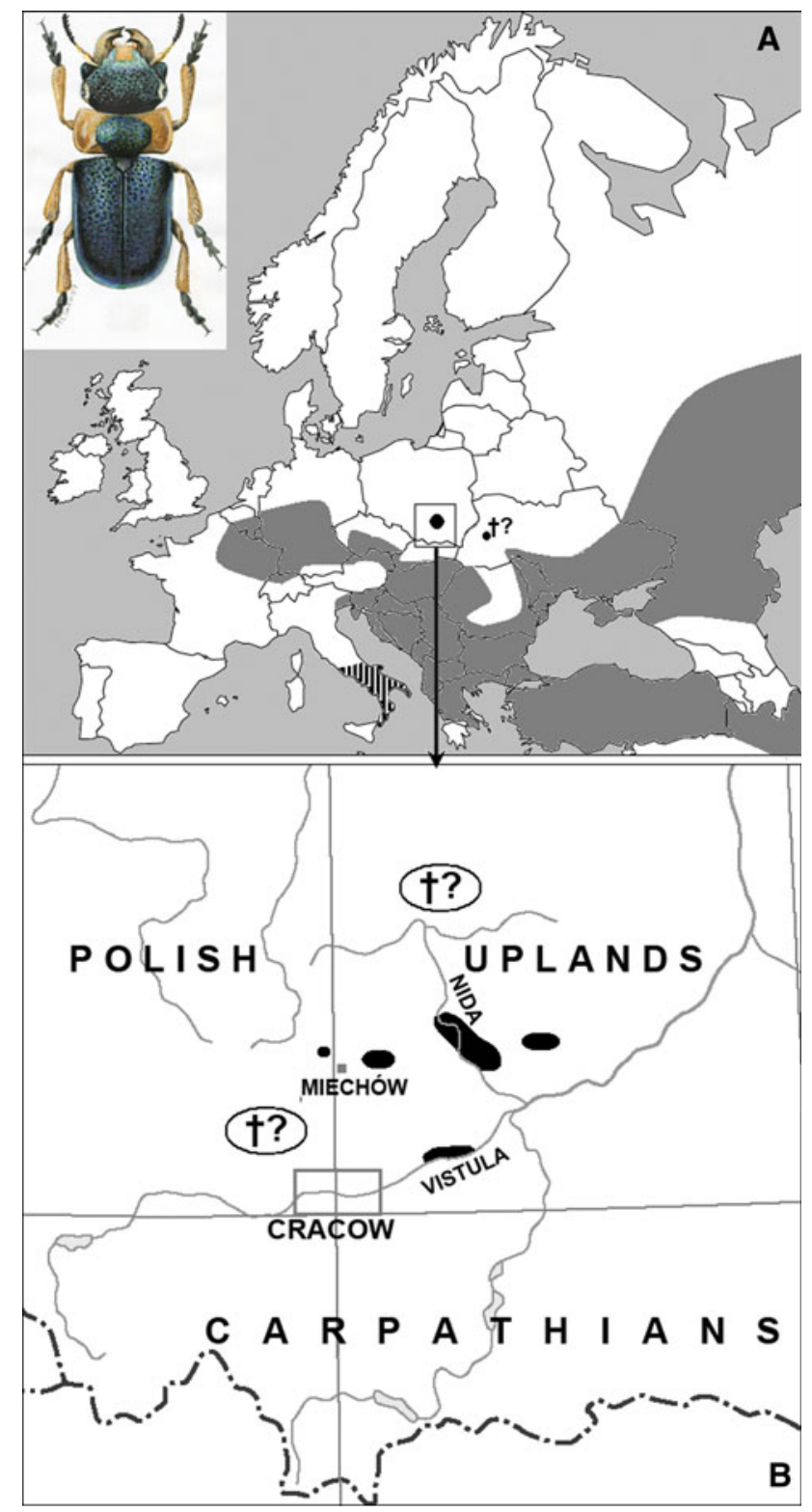

Fig. 1 Range of Cheilotoma musciformis in Europe (a) (vertical stripes-C. m. apennina; grey-C. m. musciformis; black dotsisolated populations north of Carpathians) and in Poland (b) (blackpresent distribution, $\uparrow$ ? — subpopulations probably extinct). Drawing of Cheilotoma musciformis individual by D. Filimonov

beginning of the twentieth century (Szymczakowski 1960; Burakowski et al. 1990; Warchałowski 1991). In western Ukraine, it was found in the 1930s near Rohatyn in the Western Opole Upland (Kuntze and Noskiewicz 1938) and in the 1990s in the middle part of the Dniester valley (Podolian Upland) (Pawłowski and Kubisz 2003). The taxonomic status of these highly isolated populations should be verified. C. musciformis inhabits only natural steppes and similar dry grassland habitats (e.g. xerothermic grasslands) (Burakowski et al. 1990; Ścibior 2004). The biology and ecology of this species is poorly studied. 
The eggs and larvae are known (Medvedev 1962). The host plants for this species are sainfoins Onobrychis viciifolia Scop. (Szymczakowski 1960; Warchałowski 1991), sorrel Rumex spp., common kidneyvetch Anthyllis vulneraria L. (Gruev and Tomov 1984; Warchałowski 1991) and Dorycnium Mill. (Böhme 2001). C. musciformis is rare and endangered in Central Europe, and is included in the Red Lists of endangered animals in Germany, the Czech Republic and Poland as "endangered" or "critically endangered" (Binot et al. 1998; Ścibior 2004; Pawłowski et al. 2002; Farkac et al. 2005). Its populations are threatened mainly as a result of habitat loss and fragmentation. Also genetic factors should be taken into consideration as major hazards for this species.

Molecular analyses have become an important tool in many studies of rare and threatened species (Moritz 1994; Haig 1998). The evolutionary history of populations can be investigated using genetic markers to determine whether smaller management units may exist below the species level (Moritz 1994; Knapen et al. 2003). An important issue in ecology and conservation is to understand the consequences of loss of species diversity, both at the interspecific and intraspecific level (Hughes et al. 1997; Luck et al. 2003). A restriction of gene flow among populations may have consequences for their geographical structuring, whereby local populations will only represent a subset of the range of diversity exhibited within the entire species (Hughes et al. 1997). The implication of this finding is that for the effective conservation of a particular species it becomes critical to understand the nature of population structure of that species. As some C. musciformis populations are very geographically isolated, conservation units such as "Evolutionary Significant Units" (ESUs) (Ryder 1986; Waples 1991; Moritz 1994) and "Management Units" (MUs) (Moritz 1994) may be identified. Moreover, for effective conservation it is also necessary to have in-depth knowledge of the ecology of the protected species, e.g. its host plants, which may also be studied using molecular genetics tools (Jurado-Rivera et al. 2009; Navarro et al. 2010).
The aim of this study was to evaluate the genetic diversity and isolation of $C$. musciformis populations in Poland. Furthermore, single samples from external populations (Slovakian and Ukrainian) were used for the identification of conservation units and for drawing preliminary taxonomic implications. Additionally, verification of host plants in this species populations was conducted using DNA plant barcodes.

\section{Materials and methods}

\section{Sampling}

Cheilotoma musciformis was collected from all over its Polish range, from three populations (five localities, 40 adult specimens, see Table 1). Despite many attempts, we failed to find these beetles in any locality known previously in the Krakowsko-Częstochowska Upland and the Kielce Upland. We also searched for C. musciformis in western Ukraine (in the vicinity of Rohatyn and Kamyanets Podils'kiy); however, during three attempts (2007, 2010 and 2011) we did not manage to catch any specimens. We used single museum specimen collected in 1997 in the Dniester valley (Podolian Upland, Kubisz D., Mazur M.). Also in Slovakia, we encountered substantial problems with catching these beetles, and finally, in 2011, we managed to find only one specimen in the vicinity of Bratislava. No specimens of this leaf-beetle were to be found in the collection of Comenius University in Bratislava (M. Holecová, personal communication). Additionally, single specimens of Smaragdina affinis (Illiger, 1794), Crioceris asparagi (Linnaeus 1758) and Clytra laeviuscula (Ratzeburg 1837) were collected, while Mimosestes ulkei (Horn 1873) and Donacia bicolor (Zschach 1788) sequences were downloaded from GeneBank and used as outgroups. Samples were first preserved in $99 \%$ ethanol and then stored at $-22{ }^{\circ} \mathrm{C}$. For DNA analysis, $2-10$ individuals per locality were taken.

Table 1 Localization of sampled populations

\begin{tabular}{|c|c|c|c|c|c|}
\hline Country & Region & Population & Coordinates & $\mathrm{N}$ & Year \\
\hline Slovakia & Little Carpathians & & $48^{\circ} 11^{\prime} 28.04^{\prime \prime} \mathrm{N} 16^{\circ} 59^{\prime} 45.57^{\prime \prime} \mathrm{E}$ & 1 & 2011 \\
\hline Ukraine & Podole Upland & & $48^{\circ} 37^{\prime} 10.03^{\prime \prime} \mathrm{N} 26^{\circ} 47^{\prime} 48.82^{\prime \prime} \mathrm{E}$ & 1 & 1997 \\
\hline \multirow[t]{5}{*}{ Poland } & Miechów Upland & Miechów (Tunel) & $50^{\circ} 26^{\prime} 39.08^{\prime \prime} \mathrm{N} 19^{\circ} 58^{\prime} 8.59^{\prime \prime} \mathrm{E}$ & 2 & 2011 \\
\hline & Miechów Upland & Miechów (Racławice) & $50^{\circ} 19^{\prime} 43.28^{\prime \prime} \mathrm{N} 20^{\circ} 14^{\prime} 9.80^{\prime \prime} \mathrm{E}$ & 10 & 2010 \\
\hline & Nida valley & Nida (Gacki) & $50^{\circ} 27^{\prime} 17.14^{\prime \prime} \mathrm{N} 20^{\circ} 33^{\prime} 49.59^{\prime \prime} \mathrm{E}$ & 10 & 2011 \\
\hline & Nida valley & Nida (Kików) & $50^{\circ} 24^{\prime} 46.38^{\prime \prime} \mathrm{N} 20^{\circ} 52^{\prime} 48.75^{\prime \prime} \mathrm{E}$ & 8 & 2010 \\
\hline & Vistula valley & Vistula (Hebdów) & $50^{\circ} 7^{\prime} 5.83^{\prime \prime} \mathrm{N} 20^{\circ} 22^{\prime} 12.95^{\prime \prime} \mathrm{E}$ & 10 & 2009 \\
\hline
\end{tabular}

$N$ number of sampled individuals 
Laboratory procedure

DNA was extracted from whole insect bodies using the Nucleospin Tissue Kit (Macherey-Nagel). Amplification of two markers: mitochondrial cytochrome oxidase I (COI) and nuclear Elongation Factor $1-\alpha(E F 1-\alpha)$ was performed using the following pairs of primers, respectively: C1-J2183 and TL2-N-3014 and EFs149 and EF $\alpha 1 R$ (Simon et al. 1994; Normark et al. 1999; Sanz Muñoz 2010). For museum specimen new internal primers were designated (see Table 2). The cycling profile for the PCR was: $95{ }^{\circ} \mathrm{C}$ for $4 \mathrm{~min}, 35$ cycles of $95^{\circ} \mathrm{C}$ for $30 \mathrm{~s}, 52{ }^{\circ} \mathrm{C}$ for $1 \mathrm{~min}$, $72{ }^{\circ} \mathrm{C}$ for $2 \mathrm{~min}$ and a final extension period of $72{ }^{\circ} \mathrm{C}$ for $10 \mathrm{~min}$. After purification (NucleoSpin Extract II (Macherey-Nagel)), the PCR fragments were sequenced using a BigDye Terminator v.3.1. Cycle Sequencing Kit (Applied Biosystems) and ran on an ABI 3100 Automated Capillary DNA Sequencer. All newly obtained sequences were deposited in GenBank (Accession nos.: JQ015253JQ015256 for COI of C. musciformis, JQ015257 for COI of S. affinis, JQ015258-JQ015260 for EF1- $\alpha$ of C. musciformis and JQ015261 for EF1- $\alpha$ of $S$. affinis). Moreover, sequences of other leaf-beetles were downloaded from GenBank, including Mimosestes ulkei and Donacia bicolor for COI alignments (AB499964, EU880600) and EF1- $\alpha$ (AB499964, EU880750). Amplification of plant barcodes was done using primers for intron of the tRNA-Leu intron (trnL) (A49325 and B49863; Taberlet et al. 1991) and the chloroplast maturase $\mathrm{K}$ gene (matK) (matK472F and matK1248R; Yu et al. (2011), with internal primers designated for museum sample; see Table 2). The TrnL intron has been used for host plant identification of many beetle species (Jurado-Rivera et al. 2009; Navarro et al. 2010). MatK is one of the markers which have been recently chosen as the most suitable for plant barcoding (CBOL Plant Working Group 2009). Amplification of plant barcodes was performed for two individuals from each Polish locality and for Slovakian and Ukrainian samples. All newly obtained plant barcodes were deposited in GenBank

Table 2 Internal primers used for amplification and sequencing of DNA markers from museum sample

\begin{tabular}{lll}
\hline Marker & Primers & Sequence \\
\hline COI & CO1_ChM-R1 & ATCCAAGGGCTCATAAAGTA \\
& CO1_ChM-F1 & TACTTTATGAGCCCTTGGAT \\
& CO1_ChM-R2 & TAATAGCGAATACRGCTCCT \\
& CO1_ChM-F2 & AGGAGCYGTATTCGCTATTA \\
EF1- $\alpha$ & EF $\alpha$ ChM-F1 & CTCTGCTCGCCTTCACTT \\
& EF $\alpha \_C h M-R 1$ & GTTGTTCACTCCCAAAGT \\
matK & matK_ChM-F1 & GAATGCGCCTCTTTTGATGAA \\
& matK_ChM-R2 & TTCATCAAAAGAGGCGCATTC \\
\hline
\end{tabular}

(Accession nos.: JQ708096-JQ708097 for rbcL and JQ708098-JQ708099 for matK).

Population genetics

Sequences were checked and aligned using BioEdit v.7.0.5.2 (Hall 1999) and ClustalX (Thompson et al. 1997). No indels (i.e., insertions or deletions) or internal stop codons were observed. No heterozygous EF1- $\alpha$ sequences were detected.

As no variation was observed in the nuclear marker EF1- $\alpha$ in the Polish populations, all the analyses mentioned below were conducted only for the mitochondrial (COI) marker.

Incongruence between the phylogenetic signals provided by two different DNA fragments (mitochondrial and nuclear) was assessed by statistically evaluating the incongruence length difference (ILD) index (Farris et al. 1994) using the partition homogeneity test implemented in PAUP* 4.9b10 (Swofford 2002).

Haplotypes were identified and standard genetic indices such as haplotype diversity $(h)$, nucleotide diversity $(\pi)$ and number of private haplotypes $(\mathrm{Np})$ for populations were computed using the program DnaSP v.5 (Librado and Rozas 2009). Populations were grouped according to their geographical locations (Table 1). $\mathrm{F}_{\mathrm{ST}}$ indices were calculated using ARLEQUIN 3.5 (Excoffier and Lischer 2010). A Mantel test (Mantel 1967) was performed in ARLEQUIN 3.5 to check if the genetic structure of the sampled localities (five) fits an isolation by distance model (IBD) (Slatkin 1993), using pairwise $\mathrm{F}_{\mathrm{ST}}$ values and straight-line geographic distances in kilometers. To test for the presence of contemporary or historical barriers between populations, a spatial analysis of molecular variance was conducted using the program SAMOVA (Dupanloup et al. 2002). A mismatch distribution (MD) (Rogers and Harpending 1992) and Fu's (1997) test $\left(F_{S}\right)$ were calculated for all Polish data together in ARLEQUIN 3.5 in order to examine the demographic history, and specifically, test for historical (temporal) expansions of populations.

\section{Phylogeny}

The Akaike Information Criterion in MrModeltest 2.3 (Nylander 2004) in conjunction with PAUP* (Swofford 2002) were used to determine the best-fitting nucleotide substitution model.

Two methods for phylogeny reconstruction were usedBayesian inference and parsimony (MP). Bayesian inference was run using MrBayes 3.1 (Huelsenbeck and Ronquist 2001; Huelsenbeck et al. 2001) with 1 cold and 3 heated Markov chains for 3,000,000 generations and trees were sampled every 100th generation (according to Hall 
2007). Each simulation was run twice. Convergence of Bayesian analyses was estimated using Tracer v. 1.5.0 Rambaut and Drummond (2007) and the appropriate number of sampled trees were discarded as 'burn-in', and the remainder used to reconstruct a $50 \%$ majority rule consensus tree. MP was computed using PAUP* 4.0b10. For all MP analyses, heuristic search with tree bisectionreconnection (TBR) branch swapping and random addition sequences, MaxTrees $=500$, were conducted with 500 random addition replicates. Node support was assessed with the bootstrap technique using 5,000 pseudoreplicates and TBR branch swapping. Tree reconstruction was performed separately for each marker (not shown) and for combined data. All trees were visualized with TreeView 1.6.6 (Page 1996). Pairwise distances were calculated using MEGA v.5 (Tamura et al. 2011) and uncorrected p-distances. In addition to tree, haplotype networks were constructed separately for COI and EF1- $\alpha$ using the statistical parsimony method (SP) (Templeton et al. 1992) and TCS 1.21 program (Clement et al. 2000).

\section{Host plants}

The trnL and matK sequences isolated from beetles were compared against the GenBank database using the BLASTn algorithm (Altschul et al. 1990). Identification of the most probable host plant was conducted on the basis of the highest percentage of query coverage, maximal identity and $E$ value. As Internet databases do not cover all possible host plant species and plant barcodes do not always permit species recognition, at least two most probable host plant species were described for each populations. Additionally, phylogenetic Bayesian trees were constructed using MrBayes 3.1 separately for each plant barcode, using sequences obtained from $C$. musciformis guts and on ten most similar sequences downloaded from the GenBank. To confirm that plant barcodes were sequenced actually from museum specimen and to rule out contamination, a blank sample (without DNA) and a sample of Crioceris quatuordecimpunctata leaf-beetle (which feed exclusively on
Asparagus spp.) were amplified simultaneously with museum specimen.

\section{Results}

Population genetics

Among the Polish populations the only difference was observed in COI-one mutation in 532 nucleotide position-which distinguished specimens from the Vistula valley from all other populations (from the Miechów Upland and Nida valley). This gives only two COI haplotypes for the Polish populations (Figs. 2, 3a). EF1- $\alpha$ was monomorphic in all studied specimens from Poland (Figs. 2, 3b). Such a low (COI) or nonexistent (EF1- $\alpha$ ) genetic variability in the Polish populations makes any calculations of diversity indices pointless, as considering the populations and sampled localities separately, all of them have zero haplotype and nucleotide diversities. The results for all Polish populations together were $h=0.385$ $(\mathrm{SD}=0.07)$ and $\pi=0.00048(\mathrm{SD}=0.00029)$ for $\mathrm{COI}$, and both $h$ and $\pi$ were 0.0 for EF1- $\alpha$. Different haplotypes (private haplotypes) (COI and EF1- $\alpha$ ) were characteristic of Slovakian, Ukrainian and Polish samples (no haplotype was shared among these regions). Also in Poland, the population from the Vistula valley had a different COI haplotype from all other populations. $\mathrm{F}_{\mathrm{ST}}$ indices had values of 0.0 between Miechów and Nida populations (statistically non significant) and their sampled localities or 1.0 between the Vistula population and any other Polish population (significant). These values were obvious as all studied populations were not differentiated (Nida and Miechów) and fixed for different haplotypes (Vistula vs others). Both $\mathrm{Np}$ and $\mathrm{F}_{\mathrm{ST}}$ indicate that there is no isolation among the Miechów and Nida populations, but the Vistula population is isolated in respect to the two others. The Mantel test turned out to be non-significant ( $\mathrm{r}=$ $-0.003482 ; p=0.623$ ), so no isolation-by-distance was detected. SAMOVA analyses showed that all variation $(100 \%)$ had a source among the groups of populations,
Fig. 2 Phylogenetic tree of four Cheilotoma musciformis haplotypes and outgroups constructed using combined sequences (COI-EF1- $\alpha$ ). Upper numbers indicate posterior probabilities of Bayesian inference, lower numbersbootstrap values for maximum parsimony trees (shown only if above 0.50 and $50 \%$, respectively)

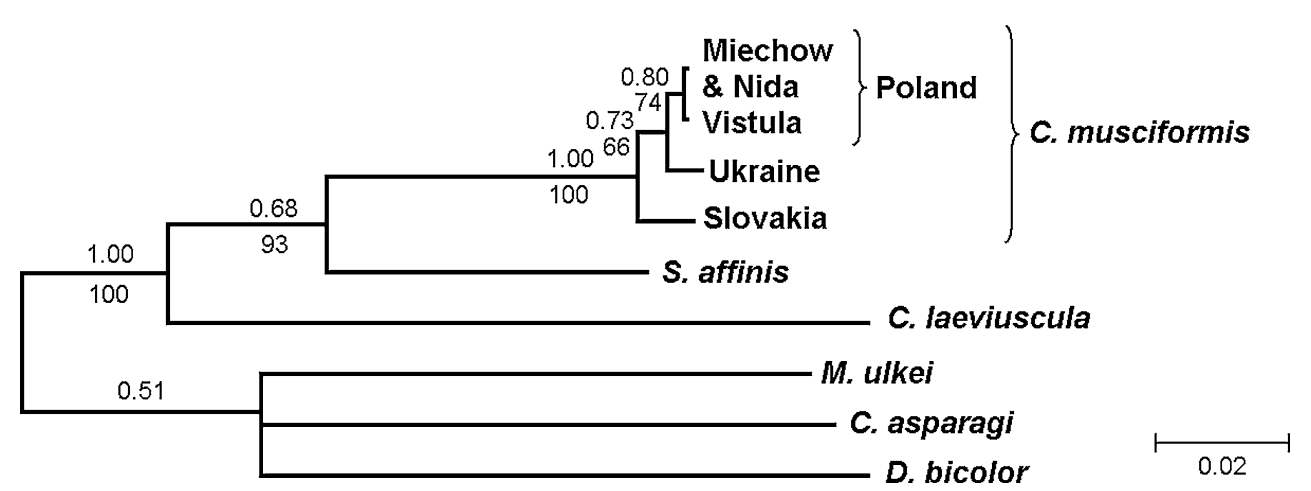



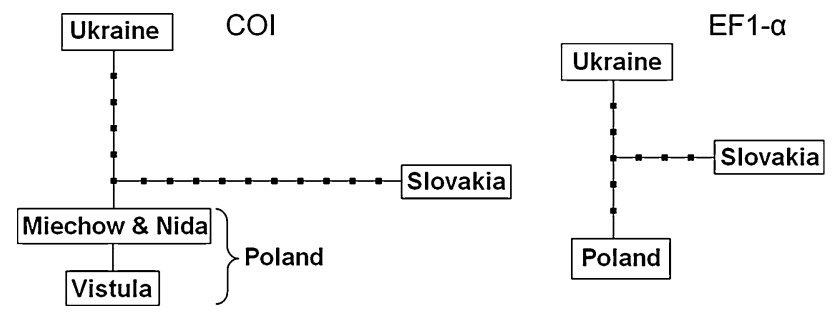

Fig. 3 Networks of Cheilotoma musciformis haplotypes using COI and $\mathrm{EF} 1-\alpha$ markers

regardless of whether they were divided into two groups (Miechów + Nida vs. Vistula) or three groups (Miechów vs. Nida vs. Vistula). The MD was unimodal (not shown) and followed the expected distribution (raggedness statistic was $0.20118, p=0.22$ ) for "recent" population growth/ decline $\quad(\tau=0.533 ; \quad 95 \% \quad$ confidence intervals $0.143-0.900)$. The expansion was not supported by Fu's test $\left(\mathrm{F}_{\mathrm{S}}=1.292, p=0.627\right)$.

Phylogenetic analyses

The GTR+I model was chosen for COI (proportion of invariable sites $\mathrm{I}=0.54 ;-\operatorname{lnL}=3,423.46$; $\mathrm{AIC}=7,060.29$ ), the $\mathrm{K} 2+\mathrm{G}$ model for EF1- $\alpha$ (gamma distribution shape parameter $\mathrm{G}=0.19 ;-\operatorname{lnL}=1,640.19 ; \mathrm{AIC}=3,314.53$ ) (Kimura 1980), GTR $+\mathrm{G}$ model was chosen for COI-EF1- $\alpha$ $(\mathrm{G}=0.27 ;-\operatorname{lnL}=-119.52 ;$ AIC $=10,287.15), \mathrm{GTR}+\mathrm{I}$ model was chosen for trnL (proportion of invariable sites $\mathrm{I}=0.65 ;-\operatorname{lnL}=1,124.93 ; \mathrm{AIC}=2,267.86)$, and $\mathrm{GTR}+\mathrm{G}$ model was chosen for matK $(\mathrm{G}=1.14 ;-\operatorname{lnL}=1,300.45$; $\mathrm{AIC}=2,618.90$ ).

Incongruence between mitochondrial and nuclear sequences was not detected by the partition-homogeneity test which was non-significant for intergenomic comparison $(p=0.62)$.

MP heuristic searches resulted in one COI tree $[$ length $=603$ steps; consistency index $(\mathrm{CI})=0.7894$; retention index $(\mathrm{RI})=0.6793$ ] based on 221 parsimonyinformative characters; four EF1- $\alpha$ trees [length $=236$ steps; $(\mathrm{CI})=0.7669$; $(\mathrm{RI})=0.6802]$ based on 96 parsimony-informative characters and two COI-EF1- $\alpha$ trees [length $=843$ steps; $(\mathrm{CI})=0.7794 ;(\mathrm{RI})=0.6725]$ based on 317 parsimony-informative characters. MP and Bayesian methods resulted in similar topologies, also topologies of trees based on single markers and joined sequences were similar, so only COI-EF1- $\alpha$ tree was presented (Fig. 2). The phylogenetic trees showed that the species $C$. musciformis formed a monophyletic clade (1.0 Posterior Probabilities, PP and $100 \%$ bootstrap, BS). All studied C. musciformis specimens formed a well-defined entity with respect to outgroups, with a p-distance of 11.6-12.1\% (COI) and $7.5-8.0 \%(\mathrm{EF} 1-\alpha)$ from the nearest outgroup
Table 3 Uncorrected p-distances (\%) among Cheilotoma musciformis populations

\begin{tabular}{llllll}
\hline & Miechów & Nida & Vistula & Ukraine & Slovakia \\
\hline Miechów & 0.0 & 0.0 & 0.1 & 0.7 & 1.7 \\
Nida & 0.0 & 0.0 & 0.1 & 0.7 & 1.7 \\
Vistula & 0.0 & 0.0 & 0.0 & 0.9 & 1.6 \\
Ukraine & 0.9 & 0.9 & 0.9 & 0.0 & 2.2 \\
Slovakia & 1.3 & 1.3 & 1.3 & 1.3 & 0.0 \\
\hline
\end{tabular}

COI above diagonal and EF1- $\alpha$ below diagonal

taxon-S. affinis (Table 3). Within C. musciformis, a similar but only slightly resolved topology of COI and EF1- $\alpha$ was observed, although the Slovakian sample was the most diverge $(1.7 \%$ distant from the Polish and $2.2 \%$ from the Ukrainian sample in respect to COI and $1.3 \%$ distant from the Polish and Ukrainian samples in respect to EF1- $\alpha$ ), followed by the Ukrainian sample (c. $0.8 \%$ distant from the Polish sample in respect to COI and $0.9 \%$ distant from the Polish sample in respect to EF1- $\alpha$ ). The same pattern of relationships of $C$. musciformis haplotypes was observed in the networks (Fig. 3).

Host plants

All studied specimens from Poland and Ukraine possessed the same trnL and matK haplotypes, however specimens from Slovakia had significantly different sequences of both barcodes. BLAST searches found that both Polish and Ukrainian $C$. musciformis specimens probably fed exclusively on Onobrychis spp. (Table 4; Fig. 4). TrnL and matK barcodes undoubtedly showed that beetles from these

Table 4 Host plant identification for Cheilotoma musciformis

\begin{tabular}{llllc}
\hline Marker & Host plant & GenBank & QC (\%) & MI (\%) \\
\hline Poland & & & & \\
matK & O. montana & AY386879 & 100 & 95 \\
& H. vicioides & HM142257 & 100 & 92 \\
trnL-intron & O. viciifolia & HM542752 & 100 & 100 \\
& O. arenaria & HM542639 & 100 & 100 \\
Ukraine & & & & \\
matK & O. montana & AY386879 & 100 & 95 \\
& H. vicioides & HM142257 & 100 & 92 \\
trnL-intron & O. viciifolia & HM542747 & 100 & 100 \\
& O. arenaria & HM542635 & 100 & 100 \\
Slovakia & & & & \\
matK & L. angustissimus & HM851122 & 100 & 99 \\
& L. corniculatus & HM049504 & 100 & 99 \\
trnL-intron & D. pentaphyllum & GQ483305 & 100 & 99 \\
& L. edulis & DQ311700 & 100 & 98 \\
\hline
\end{tabular}

$Q C$ query coverage, $M I$ maximum identity. O., Onobrychis; H., Hedarum; L., Lotus; D., Docrynium. In all E value $=0.0$ 
Fig. 4 Phylogenetic trees of trnL and matK plant barcodes obtained from Cheilotoma musciformis guts (names of populations presented) and most similar sequences downloaded from the GenBank. Numbers indicate posterior probabilities of Bayesian inference (shown only if above 0.50 )

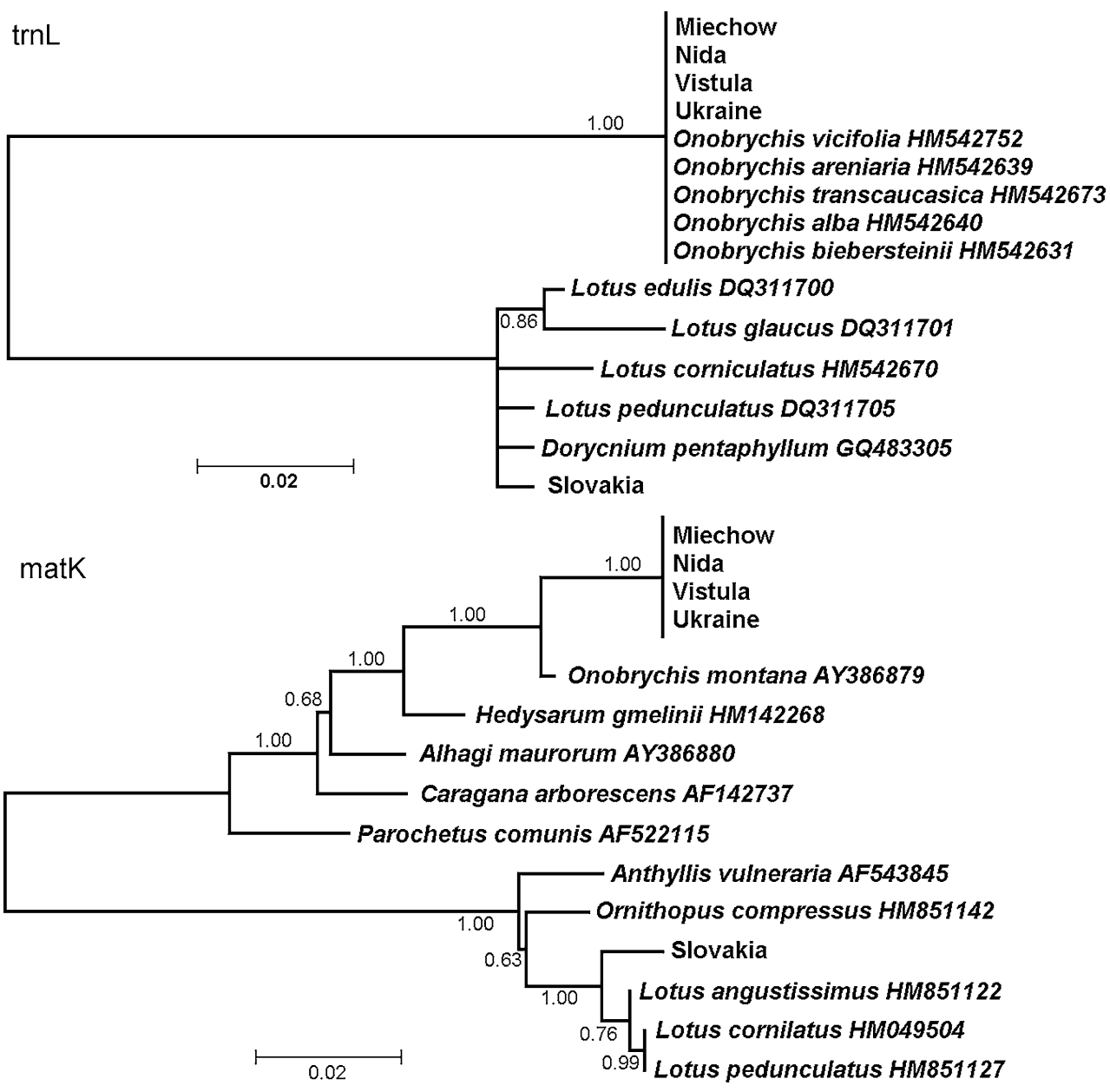

regions feed on members of the genus Onobrychis (1.00 PP for both barcodes). The other most similar matK sequences found by BLAST searching belonged to other Fabaceae (genera: Hedarum, Alhagi, Caragana, Parochetus) (also 1.0 PP; Table 4; Fig. 4). The C. musciformis specimen from Slovakia seems to feed also on Fabaceae but on different genera: Lotus spp. (1.0 PP for both markers) or Dorycnium pentaphyllum Scop. (1.0 PP according only to trnL barcode) (Table 4; Fig. 4).

\section{Discussion}

Genetic diversity of Polish populations

Cheilotoma musciformis presently inhabits only three areas in Poland: the Miechów Upland, the Nida valley and the Vistula valley on the Proszowice Plateau. C. musciformis populations in the Krakowsko-Częstochowska Upland had probably become extinct about 100 years ago in the Ojców National Park (Burakowski et al. 1990), c. 50 years ago in the Będków valley (Szymczakowski 1960) and c. 10 years ago in the vicinity of the city of Cracow (P. Szwałko, personal communication). The existence of a population in the Kielce Upland is uncertain as we failed to collect these beetles there. Populations of this species are also probably extinct in western Ukraine. Also the species $C$. musciformis is presently very rare in Slovakia (M. Holecova, personal communication). The decline and extinction lead to the conclusion that some factor adversely affected the population of this species, in particular in Central and Eastern each other as they occupy only steppe-like xerothermic grasslands which are very scarce and fragmented in Poland and adjacent countries. They are located on calcareous rocks, gypsum hills and loess scarps along larger river valleys - only in areas unsuitable for agriculture and forestry. Distances between the three Polish populations are 40-70 km of open land (mainly fields). We expected that such a high level of geographic and habitat isolation should also lead to a high level of genetic differences among the populations. However, these leaf-beetles turned out to be monomorphic (nuclear DNA) or almost monomorphic (mtDNA). The only genetic difference was found in COI sequences between the Vistula and Miechów-Nida populations (these two last populations were genetically Europe. The existing populations are highly isolated from 
identical). This difference consisted of only one mutation (substitution), but it led to an extreme (i.e. the highest possible when considering allele frequencies, but low in terms of the level of divergence) level of genetic differentiation between these two groups of populations $\left(\mathrm{F}_{\mathrm{ST}}=1.0\right)$; however, this was not correlated with geographic isolation (non-significant results of the Mantel test). There are two possible explanations for this situation. One is that C. musciformis populations in Poland are panmictic and there is no clear or significant isolation among them, maybe with the exception of the population from the Vistula valley. Nevertheless, this explanation requires the assumption that $C$. musciformis can easily migrate among the populations and their localities. This is unlikely because, despite its ability to fly, these leaf-beetles are rather poor dispersers and, moreover, they are strictly dependent on xerothermic grasslands and their host plants, Onobrychis spp., C. musciformis beetles have not been found anywhere outside xerothermic grasslands in Poland. Onobrychis can be presently found exclusively on these grasslands. In the distant past, sainfoin $(O$. arenaria) was grown as fodder for cattle, but this practice ceased a long time ago. Cheilotoma musciformis might have had greater opportunities for migration in the past, and probably later their populations became isolated. This leads to a second possible explanation. C. musciformis populations from Poland went through a strong bottleneck or founder event in the recent past, which led to a drastic reduction of their genetic diversity, and only slight differences remained between the Vistula and Miechów-Nida populations, or this mutation arose and fixed recently. If greater genetic diversity ever existed in Poland, it probably vanished together with the extinction of peripheral (westernmost and northernmost) populations. Similar level of DNA polymorphism (also only single mutation of mtDNA) was found in highly endangered Cicindela deserticoloides tiger beetle, which inhabits salt steppes in Spain (Diogo et al. 1999).

\section{Conservation units}

Even though we sampled only one specimen from the Slovakian population and one from the Ukrainian population, some conclusions can be drawn. Moderate but clear genetic distances among these three regional populations of $C$. musciformis show that they are isolated. Moreover, these differences are similar and congruent for both mitochondrial and nuclear DNA. This leads to the conclusion that all of these three populations should be considered separate conservation units, both in terms of ESU and MU. A similar pattern of genetic diversity and conservation unit designation was proposed for the weevil Centricnemus leucogrammus, which also includes isolated and genetically different populations in the Pannonian Basin, Poland and Ukraine (Kajtoch 2011). Significant genetic differences and distances of about $2 \%$ (mitochondrial) and $1 \%$ (nuclear DNA) may also suggest that $C$. musciformis musciformis is a complex of evolutionary units rather than one widespread subspecies. This concerns especially the Polish population, which is not only genetically different, but also clearly geographically separated from other populations. Such genetic distances are about two- or three-fold greater than the distances detected for populations of other xerothermic weevils: Centricnemus leucogrammus and Polydrusus inustus (Kajtoch et al. 2009, 2011). The separation of Polish and Slovakian populations was also supported by differences between the host plants (see next section). These evolutionary units may be but do not need to be identified with particular taxonomic units. Prior to the designation of any such taxonomic units, further research concerning more populations and individuals from the whole $C$. musciformis range must be undertaken.

\section{Host plants}

Plant barcodes support previous data (Szymczakowski 1960; Warchałowski 1991) that C. musciformis feed on Onobrychis spp.; however, BLAST searches and the low resolution of sequences deposited in GenBank do not yield conclusive results as to which Onobrychis species is the host plant. Probably this leaf-beetle feeds on both Onobrychis species which can be found in xerothermic grasslands and steppes (O. viciifolia and $O$. arenaria) but not on $O$. montana, as this species is restricted only to higher mountains. In the studied populations, no individual fed on Anthyllis or Rumex, so at least in Poland this leaf-beetle seems to be monophagous (limited to only Onobrychis), but this may change if more individuals are studied. Also a single specimen from Ukraine fed on Onobrychis spp. This is a very interesting result as, to the best of our knowledge, no other study has shown that host plant DNA could be isolated and amplified from museum specimens. Still, this specimen was not very old (c. 14 years old) and the plant barcodes had quite short sequences (c. $400 \mathrm{bp}$ for trnL and two fragments of c. $300 \mathrm{bp}$ for matK), which made PCR possible. An interesting finding is that a $C$. musciformis specimen from Slovakia feed on Lotus spp. or Dorycnium pentaphyllum (both Fabaceae), which supports the findings of Böhme (2001). These plants have not been reported as host plants for C. musciformis, so our results are the first to prove that this species can feed on different plant species in different parts of its range. Some discrepancy of host plant identification based on two plant barcodes used in this work are probably caused by two factors. One is the low resolution power of barcode genes for plant species identification. Second is the much larger database available for the trnL barcode than for matK gene in the GenBank. This 
large accessibility of trnL sequences in GenBank make this gene more useful for ecological studies than other standard plant barcodes (like rbcL and matK genes; CBOL Plant Working Group 2009). And indeed, trnL barcode has been successfully used in studies on host plant-beetles interactions (Jurado-Rivera et al. 2009; Navarro et al. 2010).

\section{Conclusions}

Clear differences between the Polish populations and the outermost ones (southern and eastern) prove that $C$. musciformis is Poland represents a distinct genetic unit, which should be taken into account in conservation planning and should be verified taxonomically. Also information on host plants can be a valuable tool for conservation planning in respect of this leaf-beetle in Poland. As this species is very rare and endangered in Poland and its range has been shrinking, some conservation action must be undertaken. The most probable actions include translocations of individuals among populations and the reintroduction of this beetle in some previously inhabited localities or in new places. In such localities it is essential to assure the presence of Sainfoins on xerothermic grasslands in good condition (dry grasslands without weeds, shrubs or trees). The almost complete absence of genetic diversity of Polish populations does not augur well for this species due to possible problems with inbreeding and a risk of extinction of some populations, which has probably happened to the northernmost and westernmost ones in the near past. As Polish $C$. musciformis is distinct from other populations of this beetle, the responsibility for this unit rests with Poland, and it is not enough to just include this species in the Red Data Book of Endangered Animals. C. musciformis must be protected by Polish law, and special protection of its populations and habitats should be started immediately.

Acknowledgments We would like to express our sincerest gratitude to Milada Holecová who helped us collect beetles in Slovakia, Wiesław Babik for improving the first draft of this article and Dimitrij Filimonov for kindly drawing a picture of Cheilotoma musciformis. This work was supported by grant N N303 311137 from the Polish Ministry of Higher Education and Science (Kubisz D.) and partially financed by grant 2011/01/B/NZ8/01491 from Polish National Science Centre (Kajtoch Ł.).

Open Access This article is distributed under the terms of the Creative Commons Attribution License which permits any use, distribution, and reproduction in any medium, provided the original author(s) and the source are credited.

\section{Reserences}

Altschul SF, Gish W, Miller W, Myers EW, Lipman DJ (1990) Basic local alignment search tool. J Mol Biol 215:403-410
Ashcroft MB (2010) Identifying refugia from climate change. J Biogeogr 37:1407-1413

Binot M, Bless R, Boye P, Gruttke H, Pretscher P (eds) (1998) Rote Liste gefährdeter Tiere Deutschlands. Schriftenr Landschaftpfl Natursch 55:1-434

Böhme J (2001) Phytophage Käfer und ihre Wirtspfl anzen in Mitteleuropa. Ein Kompendium. Bioform, Heroldsberg

Burakowski B, Mroczkowski M, Stefańska J (1990) ChrząszczeColeoptera. Stonkowate-Chrysomelidae, cz. 1. Katalog fauny Polski. PWN, Warszawa

CBOL Plant Working Group (2009) A DNA barcode for land plants. Proc Natl Acad Sci USA 106:12794-12797

Clement M, Posada D, Crandall KA (2000) TCS: a computer program to estimate gene genealogies. Mol Ecol 9:1657-1659

Cremene C, Groza G, Rakosy L, Schileyko A, Baur A, Erhardt A, Baur B (2005) Alterations of steppe-like grasslands in Eastern Europe: a threat to regional biodiversity hotspots. Conserv Biol 19:1606-1618

Diogo AC, Vogler AP, Gimenez A, Gallego D, Galian DJ (1999) Conservation genetics of Cicindela deserticoloides, an endangered tiger beetle endemic to southeastern Spain. J Insect Conserv 3:117-123

Dupanloup I, Schneider S, Excoffier L (2002) A simulated annealing approach to define the genetic structure of populations. Mol Ecol 11:2571-2581

Excoffier L, Lischer HEL (2010) Arlequin suite ver 3.5: a new series of programs to perform population genetics analyses under Linux and Windows. Mol Ecol Resour 10:564-567

Farkac J, Král D, Škorpík M (2005) List of threatened species in Czech Republic. Invertebrates. Available at: http://www.nationalredlist. org/site. aspx? \&species=18217\&pageid=116

Farris JS, Källersjo M, Kluge AG, Bult C (1994) Testing significance of incongruence. Cladistics 10:315-319

Frankham R, Ballou JD, Briscoe DA (2002) Introduction to conservation genetics. Cambridge University Press, Cambridge

Fu X-Y (1997) Statistical tests of neutrality of mutations against population growth, hitchhiking and background selection. Genetics 147:915-925

Goloborod'ko KK, Fedenko VS (2008) Parameters of the wing coloration in the butterfly genus Colias Fabr. (Lepidoptera, Pieridae) of the steppe zone of eastern and Central Europe. Entomol Rev 87:1109-1114

Gruev B, Tomov V (1984) Coleoptera, Chrysomelidae. Part I. Fauna Bulgarica 13:1-218

Haig SM (1998) Molecular contributions to conservation. Ecology 79:413-425

Hall TA (1999) BioEdit: a user-friendly biological sequence alignment editor and analysis program for Windows 95/98/NT. Nucleic Acids Symp Ser 41:95-98

Huelsenbeck JP, Ronquist F (2001) MRBAYES: Bayesian inference of phylogeny. Bioinformatics 17:754-755

Huelsenbeck JP, Ronquist F, Nielsen R, Bollback JP (2001) Bayesian inference of phylogeny and its impact on evolutionary biology. Science 294:2310-2314

Hughes J, Daily BGC, Ehrlich PR (1997) Population diversity: its extent and extinction. Science 278:689-692

Jurado-Rivera JA, Vogler AP, Reid CAM, Petitpierre E, GómezZurita J (2009) DNA barcoding insect-hostplant associations. Proc R Soc B Biol Sci 276:639-648

Kajtoch $€$ (2011) Conservation genetics of xerothermic beetles in Europe: the case of Centricnemus leucogrammus. J Insect Conser 15:787-797

Kajtoch Ł, Lachowska-Cierlik D (2009) Genetic constitution of parthenogenetic form of Polydrusus inustus (Coleoptera: Curculionidae)—hints of hybrid origin and recombinations. Folia Biol 57:149-156 
Kajtoch Ł, Lachowska-Cierlik D, Mazur M (2009) Genetic diversity of xerothermic weevils Polydrusus inustus and Centricnemus leucogrammus (Coleoptera: Curculionidae) in central Europe. Eur J Entomol 106:325-334

Kajtoch Ł, Korotyaev B, Lachowska-Cierlik D (2011) Genetic distinctness of parthenogenetic forms of European Polydrusus weevils of the subgenus Scythodrusus. Insect Sci. doi: 10.1111/j.1744-7917.2011.01448.x

Kimura M (1980) A simple method for estimating evolutionary rate of base substitutions through comparative studies of nucleotide sequences. J Mol Evol 16:111-120

Knapen D, Knaepkens G, Bervoets L, Taylor MI, Eens M, Verheyen E (2003) Conservation units based on mitochondrial and nuclear DNA variation among European bullhead populations (Cottus gobio L., 1758) from Flanders, Belgium. Conserv Genet 4: 129-140

Kostrowicki AS (1953) Studia nad fauną motyli wzgórz kserotermicznych nad dolną Nidą. [Studies on butterflies fauna of xerothermic hills in vicinity of Nida valley]. Fragm faun Mus Zool Polon Warszawa 6:263-447

Kubisz D, Kajtoch Ł, Mazur MA, Rizun V (2012) Molecular barcoding for central-eastern European Crioceris leaf-beetles (Coleoptera: Chrysomelidae). Central Eur J Biol 7:69-76

Kuntze R, Noskiewicz J (1938) Zarys zoogeografii polskiego Podola. Prace Nauk. TN, Lwów

Liana A (1987) Orthoptera of xerothermic habitats in Poland and their origin. In: Baccetti B (ed) Evolutionary biology of orthopteroid insects. Ellis Horwood, Chichester, pp 342-346

Librado P, Rozas J (2009) DnaSP v5: a software for comprehensive analysis of DNA polymorphism data. Bioinformatics 25: $1451-1452$

Luck GW, Daily GC, Ehrlich PR (2003) Population diversity and ecosystem services. TREE 18:331-336

Mantel N (1967) The detection of disease clustering and a generalized regression approach. Cancer Res 27:209-220

Mazur M (2001) Ryjkowce kserotermiczne Polski (Curculionoidea: Nemonychidae, Attelabidae, Apionidae, Curculionidae). Studium zoogeograficzne. Monografie Fauny Polski, Institute of Systematics and Evolution of Animals, PAS, Krakow

Mazur M, Kubisz D (2000) Ochrona owadów siedlisk kserotermicznych Polski [Insect conservation in xerothermic habitats in Poland]. Wiadomości Entomologiczne 2:129-137

Medvedev LN (1962) Sistematika i biologia lichinok podsemeistva Clytrinae (Coleoptera, Chrysomelidae). Zool Zhurnal 41(9):1334-1344

Medvedev LN (2004) Revision of the genus Cheilotoma Chevrolat, 1837 (Coleoptera: Chrysomelidae: Clytrinae). Russ Entomol J 13:35-39

Michalik S, Zarzycki K (1995) Management of xerothermic grasslands in Poland: botanical approach. Colloq Phytosiol 24: 881-895

Moritz C (1994) Defining "Evolutionarily Significant Units" for conservation. TREE 9:373-375

Navarro SP, Jurado-Rivera JA, Gomez-Zurita J, Lyal CHC, Vogler AP (2010) DNA profiling of host-herbivore interactions in tropical forests. Ecol Entomol 35:18-32

Normark BB, Jordal BH, Farrell BD (1999) Origin of a haplodiploid beetle lineage. Proc R Soc B Biol Sci 266:2253-2259

Nylander JAA (2004) MrModeltest v2. Program distributed by the author. Evolutionary Biology Centre, Uppsala University

Page RDM (1996) TREEVIEW: an application to display phylogenetic trees on personal computers. Comput Appl Biosci $12: 357-358$

Palao FMM (1909) Saneamiento de tierras húumedas y salobreñas. Tip. J. A. Jiménez. Murcia
Pawłowski J, Kubisz D (2003) Aktualny stan inwentaryzacji chrząszczy (Coleoptera) Miodoborów i pobliskich terenów Podola. In: Rola obszarów chronionych Zachodniego Podola i Jury Ojcowskiej w utrzymaniu różnorodności biologicznej i krajobrazowej. Zbiór prac naukowych. Pryrodnyi Zapovidnyk „Medobory”, Hrymailiv, pp 481-489

Pawłowski J, Kubisz D, Mazur M (2002) Coleoptera. In: Głowaciński Z (ed) Red list of threatened animals in Poland. Polish Academy of Sciences, Institute of Nature Conservation PAS, Kraków, pp 88-110

Rambaut A, Drummond AJ (2007) Tracer v1.4. Distributed by the authors. Available from: http://beast.bio.ed.ac.uk/Trace

Regalin R, Medvedev LN (2010) Tribe Clytrini Kirby, 1837. In: Löbl I, Smetana A (eds) Catalogue of Palaearctic Coleoptera. Vol. 6 Chrysomeloidea. Apollo Books, Stenstrup

Rogers AR, Harpending H (1992) Population growth makes waves in the distribution of pairwise genetic differences. Mol Biol Evol 9:552-569

Ryder OA (1986) Species conservation and systematics: the dilemma of the subspecies. TREE 1:9-10

Sanz Muñoz S (2010) Analysis of nuclear markers in two species with highly divergent mtDNA lineages in Iceland: ITS in Crangonyx islandicus and EF alpha in Apatania zonella. University of Iceland Life and Environmental Sciences. http://skemman.is/ stream/get/1946/5408/16185/1/Analysis_of_nuclear_markers_ in_two_species_with_highly_divergent_mtDNA_lineages_in_ Iceland_.pdf

Ścibior R (2004) Cheilotoma musciformis (Goeze, 1777). In: Głowaciński Z, Nowacki J (eds) Polish Red Data Book of Animals. Invertebrates. Institute of Nature Conservation PAS, Kraków, Poznań, pp 156-157

Simon C, Frati F, Bechenbach A, Crespi B, Liu H, Flock P (1994) Evolution, weighting, and phylogenetic utility of mitochondrial gene sequence and compilation of conserved polymerase chain reaction primers. Ann Entomol Soc Am 87:651-701

Slatkin M (1993) Isolation by distance in equilibrium and nonequilibrium populations. Evolution 47:264-279

Swofford DL (2002) PAUP*. Phylogenetic analysis using parsimony (* and other methods). Sinauer Associates, Sunderland, MA

Szymczakowski W (1960) Materiały do poznania kserotermofilnej fauny chrząszczy Wyżyny Małopolskiej. Pol Pismo Ent 14:173-242

Taberlet P, Gielly L, Pautou G, Bouvet J (1991) Universal primers for amplification of three noncoding regions of chloroplast DNA. Plant Mol Biol 17:1105-1109

Tamura K, Peterson D, Peterson N, Stecher G, Nei M, Kumar S (2011) MEGA5: molecular evolutionary genetics analysis using maximum likelihood, evolutionary distance, and maximum parsimony methods. Mol Biol Evol 28:2731-2739

Templeton AR, Crandall KA, Sing CF (1992) A cladistic analysis of phenotypic associations with haplotypes inferred from restriction endonuclease mapping and DNA sequence data. III. Cladogram estimation. Genetics 132:619-633

Thompson JD, Gibson TJ, Plewniak F, Jeanmougin F, Higgins DG (1997) The ClustalX windows interface: flexible strategies for multiple sequence alignment aided by quality analysis tools. Nucleic Acids Res 24:4876-4882

Varga Z (2001) Post-glacial dispersal strategies of Orthoptera and Lepidoptera in Europe and in the Carpathian basin. In: Proceedings 13th international colloquium European Invertebrate Survey, September 2001, pp 93-105

Waples RS (1991) Pacific salmon, Oncorhynchus spp., and the definition of "species" under the endangered species act. US Natl Mar Fish Serv Mar Fish Rev 53:11-22

Warchałowski A (1991) Chrysomelidae stonkowate (Insecta: Coleoptera). Cz. II (podrodziny: Clythrinae i Cryptocephalinae). Fauna Polski, Vol. 13. PWN, Warszawa 
Warchałowski A (2003) Chrysomelidae. The leaf-beetles of Europe and the Mediterranean area. Natura Optima Dux, Warszawa

Wasowska M (2006) Chrysomelid communities (Chrysomelidae, Coleoptera) of xerothermic grasslands (Inuletum ensifoliae) in the Wyzyna Miechowska Uplands (Central Poland). Biol Bratislava 61:565-572
Willis KJ, Van Andel TA (2004) Trees or no trees? The environments of central and eastern Europe during the Last Glaciation. Quat Sci Rev 23:2369-2387

Yu J, Xue JH, Zhou SL (2011) New universal matK primers for DNA barcoding angiosperms. J Syst Evol 49:176-181 